\title{
Toxicity of the organophosphate pesticide diazinon to crayfish of differing age
}

\author{
M. Buřič • A. Kouba • J. Máchová • \\ I. Mahovská • P. Kozák
}

Received: 22 July 2011/Revised: 14 May 2012/Accepted: 23 August 2012/Published online: 5 February 2013

(C) Islamic Azad University (IAU) 2013

\begin{abstract}
Diazinon is a widely applied agricultural pesticide whose effect importantly on the environment and the possible contamination of surface waters has led to increased interest in toxicological studies. Crayfish, as an ecologically important benthic macroinvertebrate, seems to be an appropriate model organism for such assessments. Acute toxicity tests were carried out on three crayfish age groups: young-of-the-year (total length $=25.0 \pm 4.9 \mathrm{~mm}$ ), juvenile (total length $=$ $56.5 \pm 3.8 \mathrm{~mm}$ ) and adult (total length $=83.5 \pm 5.7 \mathrm{~mm}$ ). Young-of-the-year crayfish were found to be the most sensitive to diazinon $\left(96 \mathrm{~h} \mathrm{LC50}=0.15 \mathrm{mg} \mathrm{L}^{-1}\right.$ ), followed by juvenile crayfish $\left(96 \mathrm{~h} \mathrm{LC50}=0.27 \mathrm{mg} \mathrm{L}^{-1}\right)$, and adults ( 96 h LC50 $=0.51 \mathrm{mg} \mathrm{L}^{-1}$ ). Crayfish were highly sensitive to diazinon. A delayed effect of Diazinon 60EC on adults was detected $\left(144 \mathrm{~h} \mathrm{LC50}=0.44 \mathrm{mg} \mathrm{L}^{-1}\right)$ suggests functional damage from the use of sublethal concentrations.
\end{abstract}

Keywords Decapod - Developmental stages ·

Environment $\cdot$ Pesticide $\cdot$ Mortality

\section{Introduction}

Chemical pollutants are common in natural environments, and a great deal of research has been done on predicting the effects of these contaminants (Amato et al. 1992; Relyea and Hoverman 2006; Mirbagheri and Hashemi Monfared

M. Buřič $(\bowtie) \cdot$ A. Kouba · J. Máchová · I. Mahovská · P. Kozák

Faculty of Fisheries and Protection of Waters,

South Bohemian Research Center of Aquaculture and Biodiversity of Hydrocenoses, Research Institute of Fish Culture and Hydrobiology, University of South Bohemia in České Budějovice, Zátiší 728/II, 38925 Vodňany, Czech Republic e-mail: buric@frov.jcu.cz
2009). The most common type, especially in aquatic environments, is the pesticide. Aquatic habitats throughout the world are contaminated with at least one pesticide, and commonly with complex mixtures including, e.g., atrazine, chlorpyrifos, diazinon, and malathion (Battaglin et al. 2003; Daly et al. 2007; Banaee et al. 2011).

Diazinon is an organophosphorus pesticide widely used on agricultural crops. It is an active ingredient in many commercial repellents (Burkepile et al. 2000), is used to control agricultural soil-dwelling insects, and as a sheep dip to control ectoparasites (Tomlin 1997; Virtue and Clayton 1997). Many river catchments throughout the world are seriously polluted by diazinon, especially in areas of intensive agriculture or extensive sheep rearing (Banaee et al. 2011; Scholz et al. 2000; Adedeji et al. 2009; Arjmandi et al. 2010). Recent studies cite a wide range of direct and indirect negative impacts of diazinon on aquatic biota, including dramatic reduction of zooplankton (Giddings et al. 1996); possible lethal effects on fish (Máchová et al. 2007; El-Sherif et al. 2009) and amphibians (Sparling and Fellers 2007); disruption of behavior patterns (Scholz et al. 2000); reduction in phytoplankton and periphyton (Relyea 2009); sublethal effects on olfactory functions (Moore and Waring 1996); changes in the erythocyte and leucocyte profile in fish probably due to the disruption of hematopoiesis or a decrease in non-specific immunity (Adedeji et al. 2009); cytotoxicity, endocrine disruption (Bisson and Hontela 2002); and indirect effects on growth and metamorphosis of tadpoles due to direct effects on zooplankton, phytoplankton, and periphyton (Relyea 2009). In addition, diazinon is listed as potentially carcinogenic (Beane Freeman et al. 2005).

Crayfish, as representatives of large crustaceans, are ecologically important benthic macroinvertebrates, and are often key species in both still and running waters (Momot 1995). Despite this, and the fact that the most sensitive 
organisms to diazinon were shown to be Crustacea (draft ambient aquatic life water quality criteria diazinon), relatively little is known about the lethal effects of diazinon on crayfish and their different developmental stages.

The main aim of the present study was to assess the effects of diazinon on crayfish, an ecologically important aquatic organism of benthic niches, in particular to describe the sensitivity of crayfish at different developmental stages [youngof-the-year (YOY), juveniles, and adults] to diazinon. The research work was conducted in research facilities of South Bohemian University, Faculty of Fisheries and Protection of Waters in Vodňany, Czech Republic in the summer 2009.

\section{Materials and methods}

Tested preparation

Diazinon [(O,O-diethyl-0-2-isopropyl-4-methylpyrimidinyl4-yl)-thiophosphate] stock solutions were prepared using Diazinon 60EC preparation (Nippon Kayaku Co., Ltd., Japan) at a concentration of $600 \mathrm{~g} \mathrm{~L}^{-1}$.

\section{Animals}

The organisms tested were selected with consideration of the status of crayfish in Europe. Autochthonous crayfish are endangered, and their sources are limited, making their use for toxicity tests unethical. Thus non-native spiny-cheek crayfish (Orconectes limosus) and signal crayfish (Pacifastacus leniusculus) from own cultures were used. Three age groups were tested: YOY c. 100 days' old spiny-cheek crayfish [total length (TL) mean $\pm \mathrm{SD}=25.0 \pm 4.9 \mathrm{~mm}$ ]; and signal crayfish juveniles, age $1+(\mathrm{TL}=56.5 \pm$ $3.8 \mathrm{~mm})$; and adults $>2$ years' old $(\mathrm{TL}=85.6 \pm 5.7 \mathrm{~mm})$. Tested animals were fed by fresh and frozen zooplankton (YOY) and frozen chironomid larvae (juveniles, adults) before the tests conducted.

\section{Acute toxicity tests}

Acute toxicity tests were performed in compliance with the International Organization for Standardization (1984) with one modification; the bath was not changed during the test, since the active substance, diazinon, decomposes to toxic diazoxon, and test results would have been affected by bath exchanges. For all tested groups, artificially prepared adulterating water was used according to the above standard. All tests were conducted in triplicate. Preliminary tests were conducted to determine the optimal concentration range for acute toxicity tests. In accordance to preliminary tests, diazinon concentrations of $0,0.05,0.1,0.2,0.3,0.4$, and $0.5 \mathrm{mg} \mathrm{L}^{-1}$ were used for all groups. Temperature, oxygen level, and $\mathrm{pH}$ were measured daily (Table 1). Young of year were placed into small circular glass tanks (150 $\mathrm{mm}$ in diameter) containing $300 \mathrm{~mL}$ of bath. Juveniles and adults were kept in aquaria with a $10,000 \mathrm{~mL}$ bath. Each trial comprised ten specimens. The light regime was natural ambient. Crayfish were not fed during the tests.

Test groups were monitored three times per day, and dead specimens were removed. Acute toxicity tests lasted for $96 \mathrm{~h}$ in all groups with the exception of a prolonged mortality observation (144 h) in the adult group. Results were processed by probit analysis, $96 \mathrm{~h} \mathrm{LC50}$ and confidence limits were calculated (The EKOTOX 5.1 software (INGEO Liberec, Czech Republic).

\section{Results and discussion}

Young-of-the-year

Excited behavior (fast and chaotic movement outside the shelters, specimens attempting to "escape") was observed at the three highest concentrations $\left(0.3,0.4\right.$, and $\left.0.5 \mu \mathrm{g} \mathrm{L}^{-1}\right)$ directly after stocking. No extraordinary behavior was seen at other concentrations. Greatest mortality occurred during the first $24 \mathrm{~h}$. Mortality after $96 \mathrm{~h}$ is shown in the Table 2. Calculated 96 h LC50 values with confidence intervals are given in Table 3. Mortality in the control group was zero.

Juveniles

Reaction to test preparations was slower than in YOY. The highest mortality occurred $72 \mathrm{~h}$ after initial exposure. A lower mortality rate was found at lower concentrations (Table 2) and, therefore lower 96 h LC50 values (Table 3). Mortality in the control group was zero.

Adults

Reaction to test preparations was slower than in juveniles. The highest mortality occurred as long as $72 \mathrm{~h}$ after initial exposure and was relatively constant until the end of treatment. Generally, adults showed lower mortality rates than did YOY and juveniles (Table 2). Table 3 presents $96 \mathrm{~h} \mathrm{LC50}$ and $144 \mathrm{~h}$ LC50 values for adults. Mortality in the control group was zero.

Table 1 Water parameters during acute toxicity tests for all tested groups of crayfish

\begin{tabular}{llll}
\hline Crayfish & Temperature $\left({ }^{\circ} \mathrm{C}\right)$ & Oxygen level $\left(\mathrm{mg} \mathrm{L}^{-1}\right)$ & $\mathrm{pH}$ \\
\hline YOY & $17.8 \pm 0.16$ & $9.0 \pm 0.10$ & $7.3 \pm 0.19$ \\
Juveniles & $17.8 \pm 0.64$ & $8.8 \pm 0.15$ & $7.7 \pm 0.03$ \\
Adults & $17.0 \pm 0.34$ & $8.6 \pm 0.31$ & $7.6 \pm 0.08$ \\
\hline
\end{tabular}

Data are presented as mean \pm SD 
Table 2 Mortality of groups of crayfish at various concentrations of diazinon

\begin{tabular}{lllll}
\hline $\begin{array}{l}\text { Diazinon concentration } \\
\mathrm{mg} \mathrm{L}^{-1}\end{array}$ & \multicolumn{3}{l}{ Mortality } \\
\cline { 2 - 5 } & $\begin{array}{l}\text { YOY }(96 \mathrm{~h}) \\
(\%)\end{array}$ & $\begin{array}{l}\text { Juveniles }(96 \mathrm{~h}) \\
(\%)\end{array}$ & $\begin{array}{l}\text { Adults }(96 \mathrm{~h}) \\
(\%)\end{array}$ & $\begin{array}{l}\text { Adults (144 h) } \\
(\%)\end{array}$ \\
\hline 0.05 & $3.3 \pm 4.71$ & $0.0 \pm 0.00$ & $0.0 \pm 0.00$ & $0.0 \pm 0.00$ \\
0.1 & $20.0 \pm 14.14$ & $0.0 \pm 0.00$ & $0.0 \pm 0.00$ & $0.0 \pm 0.00$ \\
0.2 & $73.3 \pm 4.71$ & $5.1 \pm 3.63$ & $3.3 \pm 4.71$ & $3.3 \pm 4.71$ \\
0.3 & $83.3 \pm 9.43$ & $12.81 \pm 3.63$ & $0.0 \pm 0.00$ & $13.3 \pm 4.71$ \\
0.4 & $86.7 \pm 9.43$ & $100.0 \pm 0.00$ & $23.3 \pm 4.71$ & $53.3 \pm 12.47$ \\
0.5 & $96.7 \pm 4.71$ & $100.0 \pm 0.00$ & $33.3 \pm 12.47$ & $63.3 \pm 18.86$ \\
Control & $0.0 \pm 0.00$ & $0.0 \pm 0.00$ & $0.0 \pm 0.00$ & $0.0 \pm 0.00$ \\
\hline
\end{tabular}

Table 396 h LC50 and confidence intervals for all test groups of crayfish and $144 \mathrm{~h} \mathrm{LC50}$ for the adult group

\begin{tabular}{lllll}
\hline $\begin{array}{l}\text { Crayfish } \\
\text { group }\end{array}$ & $\begin{array}{l}96 \mathrm{~h} \mathrm{LC}_{50} \\
\left(\mathrm{mg} \mathrm{L}^{-1}\right)\end{array}$ & $\begin{array}{l}\text { Confidence } \\
\text { interval }\end{array}$ & $\begin{array}{l}144 \mathrm{~h} \mathrm{LC}_{50} \\
\left(\mathrm{mg} \mathrm{L}^{-1}\right)\end{array}$ & $\begin{array}{l}\text { Confidence } \\
\text { interval }\end{array}$ \\
\hline YOY & 0.15 & $-0.02 ;+0.02$ & - & - \\
Juveniles & 0.27 & $-0.37 ;+0.15$ & - & - \\
Adults & 0.51 & $-1.58 ;+0.39$ & 0.44 & $-0.12 ;+0.09$ \\
\hline
\end{tabular}

Potential biological effects of diazinon, including disruption of behavior patterns and olfactory function, cytotoxicity, and endocrine effects, as well as direct toxicity have been reported (Scholz et al. 2000; Moore and Waring 1996; Bisson and Hontela 2002), but comparable data for crayfish are lacking, despite the fact that crayfish are recommended test organisms according to the reference/ standard methods of the Organization for Economic $\mathrm{Co} /$ operation and Development (OECD) (1992). There is reported the first study investigating comparative toxicity of diazinon to several age groups of crayfish.

In general, acute toxicity of diazinon differs widely among aquatic organisms such as fish [Cyprinus carpio larvae $96 \mathrm{~h} \mathrm{LC50}=1.53 \mathrm{mg} \mathrm{L}^{-1}$ (Aydın and Köprücü 2005), Poecilia reticulata $96 \mathrm{~h}$ LC50 $=3 \mathrm{mg} \mathrm{L}^{-1}$ (Máchová et al. 2007)]; cladocerans [Daphnia magna $48 \mathrm{~h}$ LC50 $=0.0024 \mathrm{mg} \mathrm{L}^{-1}$ (Burkepile et al. 2000)]; algae [Desmodesmus subspicatus $72 \mathrm{~h}$ IC50 $=10.2 \mathrm{mg} \mathrm{L}^{-1}$ (Kozák et al. 2006)]; insect larvae [Chironomus tentans $48 \mathrm{~h} \mathrm{LC50}=0.052 \mathrm{mg} \mathrm{L}^{-1}$ (Burkepile et al. 2000)]; and amphibians [Rana clamitans tadpoles $96 \mathrm{~h}$ LC50 $=$ 0.0028-0.005 $\mathrm{mg} \mathrm{L}^{-1}$ (Harris et al. 1998)]. The results (see Table 2) of the present study ( $96 \mathrm{~h}$ LC50 ranging between 0.15 and $0.51 \mathrm{mg} \mathrm{L}^{-1}$ ), showed that crayfish are, compared with other aquatic organisms, moderately sensitive to diazinon. However, the results show that diazinon is highly toxic to crayfish, confirming previous results using adult spiny-cheek crayfish ( $48 \mathrm{~h}$ LC50 $=0.23 \mathrm{mg} \mathrm{L}^{-1}$ ) (Kozák et al. 2006) (Fig. 1). Signal crayfish seem to be less sensitive than spiny-cheek crayfish (Fig. 1). The results obtained fits well to the usual view of increased mortality with increasing concentration of tested chemicals. The only one

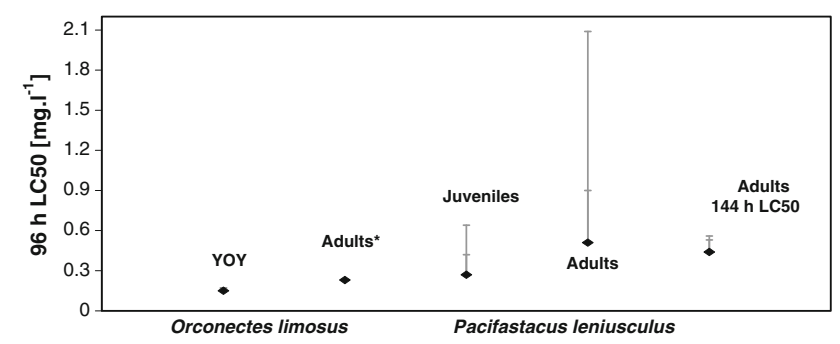

Fig. 1 Comparison of 96 h LC50 in young-of-the-year (YOY) and adult spiny-cheek crayfish, juvenile and adult signal crayfish, and $144 \mathrm{~h}$ LC50 in adult signal crayfish. The data for adult spiny-cheek crayfish (marked by asterisk) originated from work of Kozák et al. (2006). Data are presented with confidence intervals at $\alpha=0.05$

disproportion was observed when adult crayfish were tested. Mortality occurred at $0.2 \mathrm{mg} \mathrm{L}^{-1}$ diazinon, but no mortality was obtained at $0.3 \mathrm{mg} \mathrm{L}^{-1}$ (Table 2). That could be explained by a different physiological state of one crayfish (unexpected health disproportion of individual leading to higher susceptibility to diazinon) in the lower concentration. The disturbing effect is namely caused only this one crayfish. However, if the prolonged observation data $(144 \mathrm{~h})$ are taken into account (Table 2), the above mentioned disproportion disappeared.

Sublethal effects of diazinon such as olfactory inhibition and impairment of homing behavior occur at much lower concentrations $\left(0.001-0.01 \mathrm{mg} \mathrm{L}^{-1}\right.$ ) in fish (Scholz et al. 2000), which are less sensitive (acute toxicity) than crayfish. Lower diazinon concentrations may influence some physiological and behavioral cues in crayfish. Juveniles, in particular, may be affected by extremely low concentrations, due to their higher sensitivity compared to adults (Fig. 1). The higher sensitivity of juveniles to diazinon confirms the general statement of their higher vulnerability to pesticides or other environmental chemical factors (Evans and Edgerton 2002).

A small difference was observed between acute toxicity in YOY spiny-cheek crayfish and previous findings for adults (Kozák et al. 2006). Despite the expected sublethal effects on crayfish, no unusual behavior changes at lower, non-lethal, concentrations were observed. The possible physiological or behavioral reactions to sublethal doses of diazinon should be investigated. 


\section{Conclusion}

The results of the present study provide evidence of toxicological impacts of diazinon. The observed 96 h LC50 values were much higher than, e.g., the recommended effective concentration for a treatment in carp pond culture (Máchová et al. 2007). Nevertheless, possible sublethal effects of diazinon were suggested. The impact on aquatic biota is therefore too great to use diazinon for carp pond culture, or any other purpose. In addition, the representative of European native astacofauna, the noble crayfish (Astacus astacus), is more sensitive to chemical pollutants (Füreder et al. 2006; Holdich et al. 2006), and may be expected to exhibit even lower toxicity thresholds than explored in presented study. There should be the limitation of environmental contamination by diazinon and restriction of its use worldwide.

Acknowledgments Thanks The Lucidus Consultancy for language corrections and J. Hamáčková for technical support during experiments. The research was funded by the project CENAKVA No. CZ.1.05/2.1.00/01.0024, and the Grant Agency of University of South Bohemia (Project No. 047/2010/Z).

\section{References}

Adedeji OB, Adeyemo OK, Agbede SA (2009) Effect of diazinon on blood parameters in the African catfish (Clarias gariepinus). Afr J Biotechnol 8(16):3940-3946

Amato JR, Lukasewycz MT, Robert ED, Mount DI, Durhan EJ, Ankley GT (1992) An example of the identification of diazinon as a primary toxicant in an effluent. Environ Toxicol Chem 11(2):209-216

Arjmandi R, Tavakol M, Shayeghi M (2010) Determination of organophosphorus insecticide residues in the rice paddies. Int J Environ Sci Tech 7(1):175-182

Aydın R, Köprücü K (2005) Acute toxicity of diazinon on the common carp (Cyprinus carpio L.) embryos and larva. Pest Biochem Physiol 82:220-225

Banaee M, Sureda A, Mirvaghefi AR, Ahmadi K (2011) Effects of diazinon on biochemical parameters of blood in rainbow trout (Oncorhynchus mykiss). Pestic Biochem Physiol 99(1):1-6

Battaglin WA, Thurman EM, Kalkhov SJ, Porter SD (2003) Herbicides and transformation products in surface waters of the midwestern United States. J Am Water Resourc Assoc 39(4):743-756

Beane Freeman LE, Bonner MR, Blair A, Hoppin JA, Sandler DP, Lubin JH, Dosemeci M, Lynch CF, Knott C, Alavanja MCR (2005) Cancer incidence among male pesticide applicators in the agricultural health study cohort exposed to diazinon. Am J Epidemiol 162(11):1070-1079

Bisson M, Hontela A (2002) Cytotoxic and endocrine-disrupting potential of atrazin, diazinon, endosulfan, and mancozeb in adrenocortical steroidigenic cells of rainbow trout exposed in vitro. Toxicol Appl Pharmacol 180:110-117

Burkepile DE, Moore MT, Holland MM (2000) Susceptibility of five nontarget organisms to aqueous diazinon exposure. Bull Environ Contam Toxicol 64(1):114-121

Daly GL, Lei YD, Teixeira A, Muir DCG, Castillo LE, Wania F (2007) Accumulation of current-use pesticides in neotropical montane forests. Environ Sci Technol 41(4):1118-1123

El-Sherif MS, Ahmed MT, El-Danasoury MA, El-Nwishy NHK (2009) Evaluation of diazinon toxicity on nile tilapia fish (O. niloticus). J Fish Aquat Sci 4(4):169-177
Evans LH, Edgerton BF (2002) Pathogens, Parasites and Commensals. In: Holdich DM (ed) Biology of Freshwater Crayfish. Blackwell Science Ltd., London

Füreder L, Edsman L, Holdich DM, Kozák P, Machino Y, Pöckl M, Renai B, Reynolds JD, Schulz H, Schulz R, Sint D, Taugbol T, Trouilhé MC (2006) Indigenous crayfish habitat and threats. In: Souty-Groset C, Holdich DM, Noël P, Reynolds JD, Haffner P (eds) Atlas of Crayfish in Europe. Publications Scientifiques du MNHN, Paris

Giddings JM, Biever RC, Annunziato MF, Hosmer AJ (1996) Effects of diazinon on large outdoor pond microcosms. Environ Toxicol Chem 15(5):618-629

Harris ML, Bishop CA, Struger J, Ripley B, Bogart JP (1998) The functional integrity of northern leopard frog (Rana pipiens) and green frog (Rana clamitans) populations in orchard wetlands. II. Effects of pesticides and eutrophic conditions on early life stage development. Environ Toxicol Chem 17(7):1351-1363

Holdich DM, Haffner P, Noël P, Carral J, Füreder L, Gherardi F, Machino Y, Madec J, Pöckl M, Śmietana P, Taugbol T, Vigneux E (2006) Species files. In: Souty-Groset C, Holdich DM, Noël P, Reynolds JD, Haffner P (eds) Atlas of Crayfish in Europe. Publications Scientifiques du MNHN, Paris

ISO 7346/1 (1984) Determination of the acute lethal toxicity of substances to a freshwater fish-Part 1: Static method

Kozák P, Máchová J, Prokeš M, Policar T, Peňáz M, Baruš V, (2006) Toxicity of Diazinon $60 \mathrm{EC}$ for selected water organisms. In Chemical Ecology in Aquatic Systems, Firenze, Italy 16-18

Máchová J, Prokeš M, Svobodová Z, Žlábek V, Peňáz M, Baruš V (2007) Toxicity of Diazinon 60 EC for Cyprinus carpio and Poecilia reticulata. Aquacult Int 15:267-276

Mirbagheri SA, Hashemi Monfared SA (2009) Pesticide transport and transformation modeling in soil column and groundwater contamination prediction. Int J Environ Sci Tech 6(2):233-242

Momot WT (1995) Redefining the role of crayfish in aquatic ecosystems. Rev Fish Sci 3(1):33-63

Moore A, Waring CP (1996) Sublethal effects of the pesticide Diazinon on olfactory function in mature male Atlantic salmon parr. J Fish Biol 48(4):758-775

OECD Guidelines for Testing of Chemicals (2011) Organization for Economic Co/operation and Development (OECD), Paris

Relyea RA (2009) A cocktail of contaminants: how mixtures of pesticides at low concentrations affect aquatic communities. Oecologia 159:363-376

Relyea RA, Hoverman JT (2006) Assessing the ecology in ecotoxicology: a review and synthesis in freshwater systems. Ecol Lett 9:1157-1171

Scholz NL, Truelove NK, French BL, Berejikian BA, Quinn TP, Casillas E, Collier TK (2000) Diazinon disrupts antipredator and homing behaviors in Chinook salmon (Oncorhynchus tshawytscha). Can J Fish Aquat Sci 57(9):1911-1918

Sparling DW, Fellers G (2007) Comparative toxicity of chlorpyrifos, diazinon, malathion and their oxon derivatives to larval Rana boylii. Environ Pollut 147(3):535-539

Tomlin CDS (1997) The pesticide manual, 11th edn. British Crop Protection Council, Surrey

Virtue WA, Clayton JW (1997) Sheep dip chemicals and water pollution. Sci Total Environ 194-195:207-217

Draft ambient aquatic life water quality criteria diazinon, Prepared by University of Wisconsin-Superior Superior, Wisconsin 54880 and Great Lakes Environmental Center Traverse City, Michigan 49686. Prepared for U.S. Environmental Protection Agency Office of Water Office of Science and Technology Health and Ecological Criteria Division Washington, D.C. Office of Research and Development National Health and Environmental Effects Research Laboratoriem Duluth, Minnesota Narragansett, Rhode Island EPA Contract No. 68-C-98-134 